\title{
No substantial reduction of the thermic effect of a meal during pregnancy in well-nourished Dutch women
}

\author{
BY CAROLINE J. K. SPAAIJ, JOOP M. A. VAN RAAIJ, LIDWIEN J. M. VAN DER \\ HEIJDEN, FRANS J. M. SCHOUTEN, JOSÉ J. M. M. DRIJVERS, \\ LISETTE C. P. G. M. DE GROOT, HARRY A. BOEKHOLT \\ AND JOSEPH G. A. J. HAUTVAST \\ Department of Human Nutrition, Wageningen Agricultural University, Wageningen, \\ The Netherlands
}

(Received 3 December 1992 - Revised 29 March 1993 - Accepted 16 April 1993)

\begin{abstract}
To investigate changes in the thermic effect of a meal (TEM) during pregnancy, metabolic rate was measured in the fasting state and during the first $180 \mathrm{~min}$ after consumption of a standardized test meal in twenty-seven women before, and in each trimester of pregnancy. Resting metabolic rate (RMR) showed a steady increase over pregnancy: values in weeks 24 and 35 of pregnancy were significantly higher than the prepregnancy baseline (Tukey's studentized range test). The pattern of changes of postprandial metabolic rate (PPMR) was similar to that of RMR. Consequently TEM, calculated as PPMR minus RMR, did not change over pregnancy; mean TEM values $(\mathrm{kJ} / 180 \mathrm{~min})$ before and in weeks 13, 24 and 35 of pregnancy were 117.3 (SD 19.4), 116.4 (SD 23.7), 111.6 (SD 24.4) and 111.5 (SD 26.7) respectively. We consider changes in TEM of less than $15 \%$ to be of little importance physiologically. If true changes in TEM over pregnancy are $15 \%$ or more we would have had a $90 \%$ chance of observing significant changes in TEM in the present study, given the number of subjects and the methods used. Therefore, we conclude that no substantial reduction in TEM occurs during pregnancy.
\end{abstract}

Pregnancy: Thermic effect: Postprandial metabolic rate

Longitudinal studies in various countries have shown that the energy costs of pregnancy are considerable (Durnin et al. 1987; Thongprasert et al. 1987; Tuazon et al. 1987; van Raaij et al. 1987; Forsum et al. 1988). In a previous study on the energy requirements of pregnancy the question has been raised of whether processes of metabolic adaptation, resulting in a lowering of metabolic rate (MR), might occur during pregnancy (van Raaij et al. 1987). Metabolic adaptation could be reflected in a reduction in the thermic effect of a meal (TEM). So far one longitudinal study (Illingworth et al. 1987) and two crosssectional studies (Nagy \& King, 1984; Contaldo et al. 1987) have been published on this subject, but the results were inconsistent.

In the present study we tried to investigate whether TEM is reduced during pregnancy, using a longitudinal approach including baseline measurements which were carried out before the onset of pregnancy. The number of subjects in our study was sufficient to detect a $15 \%$ change in TEM with a statistical power of $90 \%$.

SUBJECTS AND METHODS

Study design

Resting MR (RMR), postprandial MR (PPMR) and body weight (BW) were measured in twenty-seven healthy Dutch women before, and in weeks 13,24 and 35 of pregnancy. TEM 
was calculated as PPMR minus RMR. MR measurements (RMR and PPMR) were carried out twice in each measurement period on two non-consecutive days within 1 week. Before pregnancy, twenty-two of the twenty-seven women had a second measurement period (two more measurement days). Afterwards it appeared that half the prepregnant measurement days fell in the preovulary and half in the postovulary phase of the menstrual cycle.

Each measurement day was preceded by $3 \mathrm{~d}$ with standardized food intake. On a measurement day the woman, who had fasted overnight, arrived by car at the metabolic unit between 07.00 and 07.30 hours. BW was measured after voiding. The woman was installed under a ventilated hood on a hospital bed. Data over the first 25 min were not used for analysis. After measurement of RMR (35 min), a liquid test meal was consumed, followed by the PPMR measurement $(180 \mathrm{~min})$. Immediately after the PPMR measurement, urine was collected quantitatively.

\section{Subjects}

For the recruitment of subjects, advertisements in local newspapers and posters spread in public buildings were used. They were living in the town of Wageningen and surrounding areas and reflected the middle-upper socioeconomic stratum. Their ethnic background was Caucasian. They were non-smokers. Participants were judged to be healthy by medical histories and urine analysis. All women gave their informed consent. The study was approved by the Ethical Committee of the Department of Human Nutrition of the Wageningen Agricultural University.

Initially thirty-eight women participated in the study. We succeeded in collecting data before and in every trimester of pregnancy from twenty-eight women. One of these women developed gestational diabetes. The present paper is based on the results of the remaining twenty-seven women. Some characteristics of these women are given in Table 1. Twentyfive infants were delivered normally and two by Caesarian section.

\section{Measurements of $M R$}

Ventilated-hood device. MR was measured by open-circuit indirect calorimetry using the ventilated-hood technique. Two hoods were connected to one set of gas analysers so that two subjects could be measured simultaneously. A perspex hood (volume 30 litres) with an air inlet on top and an air outlet at the right side was placed over the head of the woman. Fresh-filtered atmospheric air was drawn through the hood by negative pressure created by a pump downstream (model no. SCL210; Ocean, Dieren, The Netherlands). Airflow through the hood was maintained at $40 \mathrm{l} / \mathrm{min}$ by a control valve (model no. 5837; Brooks, Veenendaal, The Netherlands) and measured in the outlet airstream by a thermal mass flow meter (model no. 5812N; Brooks, Veenendaal, The Netherlands). The mass flow meter was calibrated at least once yearly by the manufacturer. Flow readings from the mass flow meter were directly converted to STPD conditions (standard temperature and pressure, dry air). A small and constant quantity of air $(0.41 / \mathrm{min})$ was continuously withdrawn by an airtight pump for $\mathrm{O}_{2}$ and $\mathrm{CO}_{2}$ analysis. Before gas analysis the sample was passed through the drying agent, $\mathrm{CaCl}_{2}$ (Merck). Through a system of computer-driven valves (model no. $211 \mathrm{~A}$; Bürker, Ingelfingen, Germany) either fresh-filtered atmospheric air, or outlet air from the ventilated hood, or calibration gas was passed to the analysers. $\mathrm{O}_{2}$ consumption and $\mathrm{CO}_{2}$ production were calculated using the Haldane correction (Jéquier, 1981).

The zero and span point of the $\mathrm{CO}_{2}$ analyser (model no. SS100; Analytical Development Company, Hoddesdon, Herts.) were calibrated using standard gases (for the zero point, pure $\mathrm{N}_{2}$; for the span point, gas mixture containing $6 \mathrm{ml} \mathrm{CO}_{2} / \mathrm{l}$ ). The zero level (no $\mathrm{O}_{2}$ ) and the span point $\left(209.5 \mathrm{ml} \mathrm{O}_{2} / \mathrm{l}\right.$ ) of the $\mathrm{O}_{2}$ analyser (model no. $1100 \mathrm{~A}$; Servomex, Zoetermeer, The Netherlands) were calibrated with pure $\mathrm{N}_{2}$ standard gas and fresh filtered atmospheric 
Table 1. Characteristics of subjects participating in the study

(Mean values and standard deviations for twenty-seven subjects)

\begin{tabular}{|c|c|c|}
\hline & Mean & SD \\
\hline Age (years)* & $29 \cdot 9$ & 3.8 \\
\hline Height (m) & 1.69 & 0.07 \\
\hline Body wt $(\mathrm{kg}) \dagger$ & $62 \cdot 8$ & $8 \cdot 5$ \\
\hline Body mass index $\left(\mathrm{kg} / \mathrm{m}^{2}\right) \neq$ & 21.8 & $2 \cdot 4$ \\
\hline Percentage body fat $\$$ & 28.7 & $5 \cdot 2$ \\
\hline Parity $\$ \S$ & 0.8 & 0.9 \\
\hline Length of gestation (wk)\| & 40.0 & $1 \cdot 3$ \\
\hline Wt gain over pregnancy $(\mathrm{kg}) \|$ & $11 \cdot 7$ & $3 \cdot 0$ \\
\hline Placental wt (g) & 657 & 114 \\
\hline Baby birth wt $(\mathrm{g})^{* *}$ & 3517 & 323 \\
\hline Baby length $(\mathrm{mm})^{* *}+\dagger$ & 510 & 51 \\
\hline Baby head circumference $(\mathrm{mm})^{* * \dagger \dagger}$ & 366 & 32 \\
\hline
\end{tabular}

* At onset of present pregnancy.

+ Before present pregnancy.

$\ddagger$ Estimated with densitometry using under-water weighing.

$\S$ Nulliparae, $n 11$; primiparae, $n 13$; multiparae, $n 3$.

$\|$ Length of gestation was derived from the first day of the woman's last reported menstrual period; classification according to Hytten (1980 b): twenty-four women 'term' (259-293 d), one woman preterm (258 d), and two women post-term (296 and $299 \mathrm{~d})$.

$\uparrow$ Last recorded weight during pregnancy ( $1-7 \mathrm{~d}$ before delivery) minus prepregnant weight.

** Sex of baby: female, $n 13$; male, $n 14$.

$\dagger \dagger$ No. of d after delivery: mean 9 (SD 4) d.

air respectively. These calibrations were carried out before the measurement of RMR; the span point of the $\mathrm{O}_{2}$ analyser was recalibrated at least every $60 \mathrm{~min}$.

Simultaneously with MR measurements, the subject's movements were recorded as an index value by a load cell (model no. TKA-200A; Tokyo Sokki Kenkyujo, Tokyo, Japan) placed under one leg of the bed on which the woman lay during the measurement.

Actual analyses were integrated over $2 \mathrm{~min}$ and printed over $2.5 \mathrm{~min}$ intervals. If both hoods were used simultaneously, one value per $5 \mathrm{~min}$ of $\mathrm{O}_{2}$ consumption $(\mathrm{ml} / \mathrm{min}), \mathrm{CO}_{2}$ production $(\mathrm{ml} / \mathrm{min})$ and body movement index was printed for each subject. If high $\mathrm{O}_{2}$ consumption and $\mathrm{CO}_{2}$ production values appeared in combination with a high body movement index, these values were excluded. Missing values also occurred when the span point of the $\mathrm{O}_{2}$ analyser was checked, or when the woman needed to visit the lavatory. Missing values were replaced by the mean of the two preceding and the two following values.

Variability. Ethanol combustion tests were carried out at least once monthly to detect systematic deviations in the ventilated hood system. In each test about $25 \mathrm{~g}$ ethanol was combusted in about $2 \mathrm{~h}$. Instead of the ventilated hood, an airtight combustion chamber was linked to air inlet and air outlet. The reproducibility of the system was determined by six alcohol combustion tests for each ventilated-hood device, carried out on separate days within a period of 2 weeks. Day-to-day coefficients of variation (\%) were $2 \cdot 1$ for $\mathrm{O}_{2}$ consumption, 1.9 for $\mathrm{CO}_{2}$ production, 1.9 for respiratory quotient and 1.9 for metabolic rate. These values agree very well with those presented by Bogardus et al. (1986).

Measurement of $N$ excretion. Subjects voided immediately after arriving at the laboratory. Urine was collected quantitatively $4 \mathrm{~h}$ later when the PPMR measurement had finished. Urine was weighed and two samples were taken which were frozen at $-20^{\circ}$. In these urine 
samples the urea concentration was determined (BV 396346 kit; Boehringer Mannheim, Almere, The Netherlands; Gutman \& Bergmeyer, 1974). Urea-N excretion was calculated by multiplication of urine weight with urea concentration. To obtain total $\mathrm{N}$ excretion the assumption was made that $85 \%$ of urinary $\mathrm{N}$ is excreted as urea (Bonsnes, 1978).

Calculation of $M R$ and non-protein respiratory quotient $(n p R Q) . \mathrm{MR}(\mathrm{kJ} / \mathrm{min})$ and $\mathrm{npRQ}$ were calculated from $\mathrm{O}_{2}$ consumed $\left(V_{\mathrm{O}_{2}} ; \mathrm{ml} / \mathrm{min}\right), \mathrm{CO}_{2}$ produced $\left(V_{\mathrm{Co}_{2}} ; \mathrm{ml} / \mathrm{min}\right)$ and $\mathrm{N}$ excretion $(\mathrm{mg} / \mathrm{min})$ using formulas given by Jéquier (1981). MR values were averaged to obtain one value per $5 \mathrm{~min}$ for each subject on each measurement day. These $5 \mathrm{~min}$ averages were used for further analyses.

\section{Standardization of diet on days before measurements}

During the $3 \mathrm{~d}$ preceding MR measurements the woman followed strict guidelines for her dietary intake. Guidelines reflected the individual energy requirement of each subject as estimated by a $5 \mathrm{~d}$ weighed food record carried out about 2 weeks before the first measurement day. Between periods, guidelines were only changed at the woman's request so that within each period the prescribed energy intake followed the subject's habitual intake. The relative amounts of protein, carbohydrate and fat were standardized at respectively 15, 50 and 35 energy \% (en\%). A maximum of one alcoholic beverage daily was allowed, replacing an equivalent amount of energy from carbohydrates. The standardization of energy intake was done because short-term over- or underfeeding (Weststrate \& Hautvast, 1990) as well as the macronutrient composition of the diet on days before measurement days (Acheson et al. 1984) might influence both RMR and TEM.

\section{$R M R$}

RMR was measured after $12 \mathrm{~h}$ fasting. On the day before a measurement day the woman refrained from intensive physical activity. During the measurement the woman was lying in a supine semi-recumbent position, in complete physical rest, but awake, watching nonstressing video films.

Analysis of variance of measurements before and during pregnancy of twenty-seven subjects with complete data revealed that the within-person day-to-day variation coefficient in RMR was $4.7 \%$, which is within the normal range (Bogardus et al. 1986; Murgatroyd et al. 1987; Piers et al. 1992). There was no systematic difference between the first and second day of measurement within the same week.

To investigate whether RMR was measured under steady-state conditions, the $35 \mathrm{~min}$ period during which RMR was measured was divided into seven periods of 5 min. Analysis of covariance with RMR as dependent variable and time as covariable revealed that there was no decrease in RMR throughout the $35 \mathrm{~min}$ of the measurement, and with Tukey's studentized range test it appeared that there were no differences between any pair of 5 min RMR values. We conclude, therefore, that the duration of the period of rest preceding the RMR measurement ( $25 \mathrm{~min}$ ) was sufficient for reaching the steady-state.

\section{$P P M R$ and TEM}

Test meal. The meal consisted of $375 \mathrm{~g}$ yoghurt-based liquid formula containing $1325 \mathrm{~kJ}$ (protein $15 \mathrm{en} \%$, fat $30 \mathrm{en} \%$, carbohydrate $55 \mathrm{en} \%$ ). The ingredients were $(\mathrm{g} / \mathrm{kg})$ : fullcream yoghurt 581 , unsweetened orange juice 323 , white sugar 65 , sunflower oil 13 , protein powder (Protifar ${ }^{\circledR}$; Nutricia Nederland BV, Zoetermeer, The Netherlands) 18. The macronutrient composition $(\mathrm{g} / \mathrm{kg}$ ) was: dry matter 205 , ash 7 , protein (Kjeldahl method; $\mathrm{N} \times 6.38$ ) 33, fat (Röse Gottlieb method) 30 and carbohydrate (calculated by subtraction) 135. Test meals were prepared in bulk in three batches, and stored at $-20^{\circ}$.

PPMR was measured during the first $180 \mathrm{~min}$ following consumption of the test meal. 
The conditions of measurement were exactly the same as those observed during the RMR measurement, except for the postprandial state. TEM was calculated as PPMR minus RMR and expressed as $\mathrm{kJ} / \mathrm{min}$ in time-response curves, or as $\mathrm{kJ} / 180 \mathrm{~min}$ if the cumulative TEM over $180 \mathrm{~min}$ is considered.

The within-person day-to-day variation coefficient of PPMR was $3.9 \%$, which resembles the value observed for RMR. The within-person day-to-day variation coefficient of TEM was $22.6 \%$. There was no systematic difference between PPMR or TEM values of the first and second day of measurement within the same week.

The duration and magnitude of TEM increases with the energy content of the meal (D'Alessio et al. 1988); thus, meal size and duration of the measurement should be well balanced to each other. We limited the postprandial period to $180 \mathrm{~min}$ to avoid stress caused by prolonged measurement, which might occur especially in late pregnancy. We chose a relatively small test meal to ensure that a $3 \mathrm{~h}$ postprandial period would cover the main part of the TEM.

A side study in which eight non-pregnant non-lactating (NPNL) women were measured at three non-consecutive days within a 2-week period, following exactly the same procedures but now up to 300 min after the test meal, revealed that $86 \%$ of the full TEM response was covered during the first $180 \mathrm{~min}$ after consumption of the test meal. The cumulative TEM over $300 \mathrm{~min}$ was $132 \mathrm{~kJ}$ (10\% of the energy content of the test meal); from 270 and 300 min after the meal PPMR was only slightly above RMR level (mean difference 0.14 (SEM 0.04) $\mathrm{kJ} / \mathrm{min}$ ). In late pregnancy some gastrointestinal responses to a meal are delayed (Hytten, 1980a), suggesting that the TEM response might be spread over a longer period and that the first $180 \mathrm{~min}$ after the meal might cover a smaller part of the TEM response than in the non-pregnant state. Therefore, in a second cross-sectional study MR was measured in the fasting state and in the period from 270 to 300 min after the meal, in five late-pregnant and eight NPNL women on three non-consecutive days within a 2week period. No difference in TEM between 270 and $300 \mathrm{~min}$ after the meal was observed between late-pregnant women (mean 0.13 (SEM 0.08) $\mathrm{kJ} / \mathrm{min}$ ) and NPNL-women (mean $0 \cdot 13$ (SEM 0.05$) \mathrm{kJ} / \mathrm{min}$ ). This result does not indicate a prolonged TEM response in late pregnancy.

\section{Statistics}

Data analysis was carried out using the program provided by Statistical Analysis Systems (SAS Institute, Inc., Cary, NC, USA). The Shapiro and Wilk tests were used to test whether data were a random sample from a normal distribution. Tukey's studentized range test (significance level $\alpha=0.05$ ) was used to investigate whether significant changes over pregnancy had occurred.

The statistical power $(1-\beta)$ or the probability or the probability to detect the physiologically important change between two periods $(\Delta)$, if this change truly exists, was determined by calculating $t_{\beta}$ (Snedecor \& Cochran, 1979):

$$
t_{\beta}=\left\{\Delta \sqrt{ } N / s_{\Delta}\right\}-t_{\alpha},
$$

where $s_{\Delta}$ is the estimated within-subject standard deviation in the change of the parameter and $N$ is the number of subjects. At an $\alpha$ of 0.05 , and a sample size of 26 (df 25), $t_{\alpha}$ is 2.060 (two-tailed). The $\beta$ of $t_{\beta}$ is read from the one-tailed $t$-distribution table (df 25).

\section{RESULTS}

\section{$R M R$ and PPMR}

RMR increased from before pregnancy to 13 weeks gestation (Table 2), but this increase did not reach statistical significance (mean difference 0.18 (SEM 0.05$) \mathrm{kJ} / \mathrm{min}$ ). In week 24 of gestation RMR was significantly higher than in week 13 (mean difference 0.34 
Table 2. Resting metabolic rate $(R M R)$, postprandial metabolic rate (PPMR) and thermic effect of a meal (TEM) before and during pregnancy in twenty-seven well-nourished Dutch women*

\begin{tabular}{|c|c|c|c|c|c|c|}
\hline \multirow[b]{2}{*}{ Period of study } & \multicolumn{2}{|c|}{$\operatorname{RMR}(\mathrm{kJ} / \mathrm{min})$} & \multicolumn{2}{|c|}{$\operatorname{PPMR} \dagger(\mathrm{kJ} / \mathrm{min})$} & \multicolumn{2}{|c|}{ TEM $+(\mathrm{kJ} / 180 \mathrm{~min})$} \\
\hline & Mean & SD & Mean & SD & Mean & SD \\
\hline Before pregnancy & $3 \cdot 76^{\mathrm{a}}$ & 0.33 & $4 \cdot 41^{a}$ & $0 \cdot 30$ & $117 \cdot 3^{\mathrm{a}}$ & $19 \cdot 4$ \\
\hline Pregnancy: week 13 & $3 \cdot 94^{\mathrm{a}}$ & 0.42 & $4 \cdot 58^{\mathrm{a}}$ & 0.41 & $116 \cdot 4^{\mathrm{a}}$ & $23 \cdot 7$ \\
\hline week 24 & $4 \cdot 28^{\mathrm{b}}$ & 0.51 & $4.90^{\mathrm{b}}$ & 0.53 & $111 \cdot 6^{\mathrm{a}}$ & $24 \cdot 4$ \\
\hline week 35 & $4 \cdot 62^{c}$ & 0.51 & $5 \cdot 24^{c}$ & 0.46 & $111 \cdot 5^{a}$ & $26 \cdot 7$ \\
\hline
\end{tabular}

$a, b, c$ Within each column, means with unlike superscript letters were significantly different (Tukey's studentized range test): $P<0.05$.

* For details of subjects and procedures, see pp. 335-339 and Table 1.

$\dagger$ Average metabolic rate during the first 180 min after the test meal.

$\ddagger$ Cumulative increase in metabolic rate above RMR level during the first 180 min after the test meal ((PPMR minus $\mathrm{RMR}) \times 180$ ).

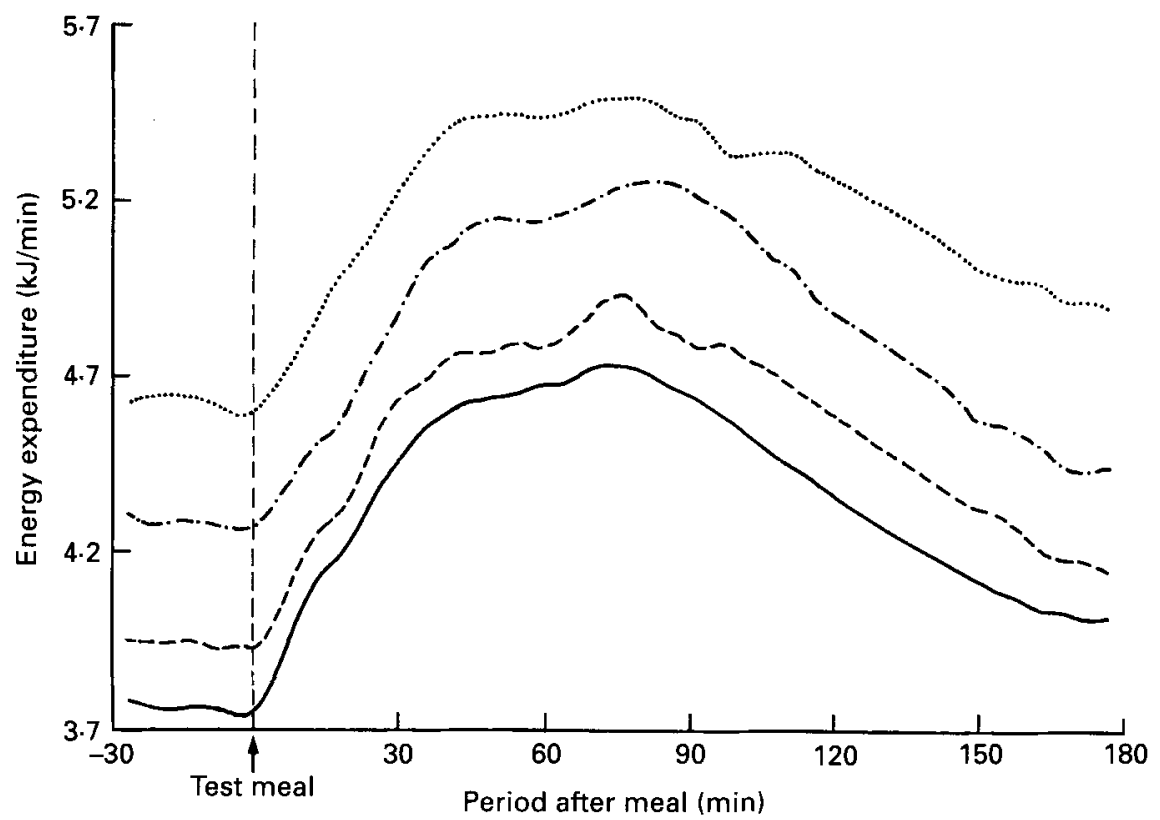

Fig. 1. Metabolic rate before and after consumption of the test meal in twenty-seven well-nourished Dutch women, before pregnancy $(-)$, and in weeks $13(---), 24(-,--)$, and $35(\cdots \cdots)$ of pregnancy. For details of subjects and procedures, see Table 1 and pp. 335-338.

(SEM 0.08$) \mathrm{kJ} / \mathrm{min}$ ). This increase was similar to that from week 24 to week 35 of gestation (mean difference 0.34 (SEM 0.07) $\mathrm{kJ} / \mathrm{min}$ ).

The differences in PPMR (average value of $180 \mathrm{~min}$ ) were very similar to the differences in RMR observed between the values before and at each trimester of pregnancy (Fig. 1 and Table 2). There was a slight but non-significant increase in PPMR from prepregnant levels to the first trimester of pregnancy (mean difference 0.18 (SEM 0.05 ) $\mathrm{kJ} / \mathrm{min}$ ). The increase from week 13 to week 24 of gestation was almost twice as large (mean 0.32 


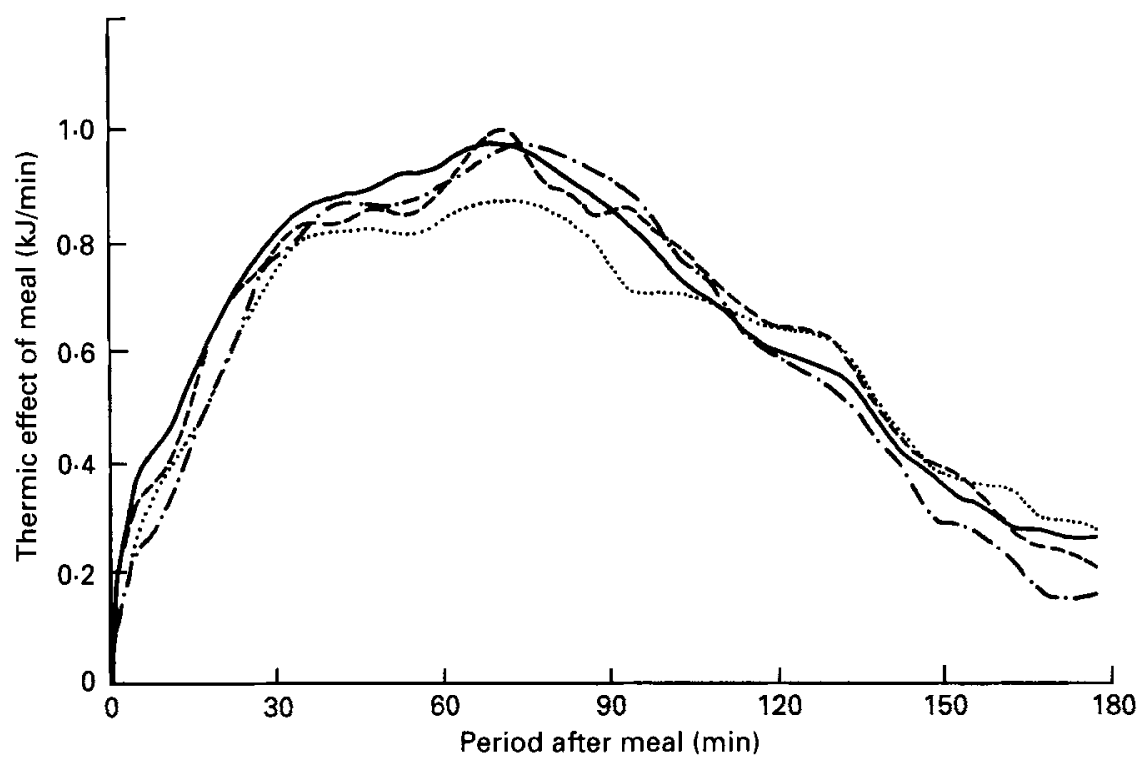

Fig. 2. Thermic effect of a meal (TEM) in twenty-seven well-nourished Dutch women, before pregnancy ( - ), and in weeks $13(---), 24(-\cdot-\cdot-)$, and $35(\cdots \cdots)$ of pregnancy. For details of subjects and procedures, see Table 1 and pp. 335-339.

$(\operatorname{SEM} 0.08) \mathrm{kJ} / \mathrm{min}$ ) and an increase of $0.34(\operatorname{SEM} 0.07) \mathrm{kJ} / \mathrm{min}$ was found from week 24 to week 35 .

\section{$T E M$}

The time-response curves of TEM are given in Fig. 2. There are only minor differences between the curves representing the prepregnant measurements and the measurements in weeks 13 and 24 of gestation. In the third trimester of pregnancy, the first 100 min after the meal TEM tended to be slightly decreased compared with prepregnant values, whereas from 100 to $180 \mathrm{~min}$ after the meal both curves followed almost the same pattern. However, none of these differences reached statistical significance. The cumulative TEM over first $180 \mathrm{~min}$ after the test meal did not change significantly over pregnancy (Table 2): the change from before pregnancy to week 13 of gestation was -0.9 (SEM 4.5 ) $\mathrm{kJ} / 180 \mathrm{~min}$, the change from week 13 to week 24 of gestation was -4.9 (SEM 4.5$) \mathrm{kJ} / 180 \mathrm{~min}$, and the change from week 24 to week 35 of gestation was -0.1 (SEM 6.0$) \mathrm{kJ} / 180 \mathrm{~min}$.

\section{Protein oxidation and $n p R Q$}

$\mathrm{N}$ excretion during the RMR and PPMR measurements diminished over pregnancy. Mean values of $\mathrm{N}$ excretion $(\mathrm{mg} / \mathrm{min})$ were: before pregnancy 10.38 (SD $2 \cdot 22)$, at 13 weeks gestation 9.48 (SD 1.38), at 24 weeks gestation 9.13 (SD 2.22), and at 35 weeks gestation 8.05 (SD 0.85). The mean reduction of $\mathrm{N}$ excretion from before pregnancy to week 13 of gestation was 0.90 (SEM 0.45) $\mathrm{mg} / \mathrm{min}$ and not significant (Tukey's standardized range test), but values at weeks 24 and 35 of gestation were significantly below prepregnancy values: mean reductions were respectively 1.25 (SEM 0.42) and 2.33 (SEM 0.54 ) $\mathrm{mg} / \mathrm{min}$.

During the RMR measurement npRQ had a mean value of 0.88 before pregnancy as well as during pregnancy (Table 3). After consumption of the test meal npRQ increased to a peak value at 60-90 min after the meal. Thereafter, npRQ decreased again. Between 90 and 150 min after the meal npRQ was significantly reduced in week 24 of gestation compared with the prepregnancy value: mean changes for the periods $90-120$ and $120-150$ min after 
Table 3. Non-protein respiratory quotient $(n p R Q) *$ before and during pregnancy in twenty-seven well-nourished Dutch women

(Mean values and standard deviations)

\begin{tabular}{|c|c|c|c|c|c|c|c|c|}
\hline & \multirow{2}{*}{\multicolumn{2}{|c|}{ Before pregnancy }} & \multicolumn{6}{|c|}{ Week of pregnancy } \\
\hline & & & \multicolumn{2}{|c|}{13} & \multicolumn{2}{|c|}{24} & \multicolumn{2}{|c|}{35} \\
\hline & Mean & SD & Mean & SD & Mean & $\mathrm{SD}$ & Mean & SD \\
\hline Fasting state & $0 \cdot 88^{\mathrm{a}}+$ & $0 \cdot 04$ & $0.88^{a}$ & 0.06 & $0 \cdot 88^{\mathrm{a}}$ & 0.05 & $0.87^{\mathrm{a}}$ & 0.05 \\
\hline \multicolumn{9}{|l|}{$\begin{array}{l}\text { Postprandial state } \\
\text { (min after meal) }\end{array}$} \\
\hline $0-30$ & $0 \cdot 88^{\mathrm{a}}$ & 0.05 & $0.89^{\mathrm{a}}$ & 0.06 & $0.90^{\mathrm{a}}$ & 0.05 & $0-88^{\mathrm{a}}$ & 0.05 \\
\hline $30-60$ & $0 \cdot 96^{\mathrm{a}}$ & 0.04 & $0.97^{\mathrm{a}}$ & 0.06 & $0.96^{\mathrm{a}}$ & 0.05 & $0.92^{\mathrm{b}}$ & 0.04 \\
\hline $60-90$ & $0.97^{\mathrm{a}}$ & 0.04 & $0.95^{\mathrm{a}}$ & 0.05 & $0.95^{\mathrm{a}}$ & 0.05 & $0.92^{\mathrm{b}}$ & 0.04 \\
\hline $90-120$ & $0 \cdot 94^{\mathrm{a}}$ & 0.04 & $0.93^{\mathrm{ab}}$ & 0.04 & $0.91^{\text {be }}$ & 0.05 & $0.90^{c}$ & 0.04 \\
\hline $120-150$ & $0.92^{\mathrm{a}}$ & 0.04 & $0.91^{\mathrm{ab}}$ & 0.05 & $0 \cdot 90^{\mathrm{b}}$ & 0.04 & $0.90^{\mathrm{h}}$ & 0.03 \\
\hline $150-180$ & $0 \cdot 89^{\mathrm{a}}$ & 0.04 & $0.87^{\mathrm{a}}$ & 0.05 & $0.87^{\mathrm{a}}$ & 0.05 & $0 \cdot 87^{a}$ & 0.04 \\
\hline
\end{tabular}

a,b.c Within each row, means with unlike superscript letters were significantly different (Tukey's studentized range test).

* Calculated as $\mathrm{CO}_{2}$ production: $\mathrm{O}_{2}$ consumption after correction for the amounts of $\mathrm{CO}_{2}$ and $\mathrm{O}_{2}$ attributable to protein oxidation.

$\dagger$ For details of subjects and procedures, see pp. 335-338 and Table 1.

the meal were -0.03 (SEM 0.01) and -0.03 (SEM 0.01) respectively. In week 35 the peak value was even smaller and values between 30 and 150 min after the meal were significantly below the prepregnant level: mean changes for the periods 30-60,60-90, 90-120 and 120-150 min after the meal were -0.04 (SEM 0.01), -0.05 (SEM 0.01), -0.04 (SEM 0.01), and -0.03 (SEM 0.01) respectively.

\section{DISCUSSION}

The women in the present study were all healthy and well-nourished. Their weight gains over pregnancy and the birth weights of their children (Table 1) were as expected for Western women eating without restriction (Hytten, 1980 b; Durnin et al. 1987; van Raaij et al. 1987). The increase of RMR over pregnancy closely resembled the pattern observed in our previous study (van Raaij et al. 1989).

The macronutrient composition of our test meal was representative for Western countries, although the fat content was a bit lower than that in the average Dutch diet ( 30 instead of $40 \mathrm{en} \%$ ). During the $180 \mathrm{~min}$ postprandial measurement period we covered the main part $(86 \%)$ of the full thermic effect of this test meal (see p. 339). It seems appropriate, therefore, to extrapolate the TEM results to total daily diet-induced thermogenesis. Still, some caution is needed as gastrointestinal responses to a liquid meal might differ from responses to the normal mixed diet.

Our results show that there is no change in TEM during pregnancy. Until now only one publication gives results on longitudinal changes in TEM during pregnancy (Illingworth $e t$ al. 1987). In that study TEM appeared to be reduced in the second $(-28 \%)$ but not in the first $(-1 \%)$ and third $(-15 \%$, not significant) trimesters of pregnancy compared with postlactational measurements. However, their study population was small $(n 7)$ and possibly not representative, since RMR in week 35 of gestation was only $7.9 \%$ higher than that in the postlactational state, which is a small increase compared with the present study and with other longitudinal studies in well-nourished populations (Durnin et al. 1987; van 
Raaij et al. 1987; Forsum et al. 1988). Two small cross-sectional studies have been published in which TEM values of pregnant women and non-pregnant control subjects were compared. Nagy \& King (1984) did not observe any difference (four late-pregnant, six early-pregnant and six non-pregnant women), but Contaldo et al. (1987) found a significantly lower TEM $(-35 \%)$ in five late-pregnant $v$. five non-pregnant women. Prentice et al. (1989) studied MR in eight women before and during their pregnancies with a whole-body calorimeter. From $24 \mathrm{~h} \mathrm{MR}$, basal MR, and MR during exercise they derived the energy costs of diet-induced thermogenesis plus minor physical movements, and found this factor to be constant throughout pregnancy.

The large within-subject variation in TEM (22.6\% in our study) might have caused the inconsistency of the previous studies (Nagy \& King, 1984; Contaldo et al. 1987; Illingworth et al. 1987; Prentice et al. 1989), which all described groups of only four to eight women. In the present study we were interested in a reduction of $15 \%$ or more in the TEM throughout pregnancy. With the mean prepregnancy energy intake of 9.6 (SEM 0.3 ) $\mathrm{MJ} / \mathrm{d}$ in our women, such reduction would result in an energy saving of about $0.15 \mathrm{MJ} / \mathrm{d}$. If a reduction in TEM of $15 \%$ really occurred, we in our study would have had a $90 \%$ chance of finding a significant reduction. Our results suggest, therefore, that it is unlikely that physiologically significant changes in diet-induced thermogenesis occur during pregnancy. More research is needed to investigate if other processes of metabolic adaptation occur during pregnancy.

The reduction in $\mathrm{N}$ excretion over pregnancy indicates that protein oxidation is diminished. This was also found by De Benoist et al. (1985) and Fitch \& King (1987). The decrease in $\mathrm{N}$ excretion might reflect the anabolic state of the body: on a daily basis a reduction with on average $1.5 \mathrm{mg} \mathrm{N} / \mathrm{min}$ could reflect accumulation of $13.5 \mathrm{~g}$ protein, which is equivalent to about $70 \mathrm{~g}$ lean tissue (Grande, 1968). However, Hytten (1980 b) estimated total protein accumulation over pregnancy to be only $925 \mathrm{~g}$, or on average about $3.5 \mathrm{~g} / \mathrm{d}$. Therefore, the reduction of $\mathrm{N}$ excretion appears to be far too high to be explained by protein accumulation. Possibly it also reflects a shift from protein oxidation towards oxidation of carbohydrates and fats. This could be a useful adaptation to the increased energy needs during pregnancy because the net ATP yield of protein is lower than the net ATP yield of an energetically equivalent amount of carbohydrate or fat (Flatt, 1985).

Fasting npRQ was unchanged over pregnancy, suggesting that the proportion of oxidized carbohydrate to oxidized fat is unchanged in the fasting state. In contrast, a progressive reduction of postprandial npRQ was observed over pregnancy. This suggests that the postprandial increase in carbohydrate oxidation gets smaller when pregnancy advances: carbohydrates appear to be saved at the expense of fats. This fits with the findings of Williams et al. (1986) that glucose uptake by adipose tissue diminishes and plasma levels of free fatty acids and glycerol increase steadily in pregnancy.

This study was supported by The Netherlands Organization for Scientific Research (NWO; project number PN 900-562-069). The authors thank the twenty-seven participants for their invaluable cooperation; doctoral students Fernie van Beest, Carola Beijen, Jeroen van Berkum, Polly Boon, Anne Linda van Kappel, Titia Lekkerkerk, Nadia Lysens, Saskia de Pee, Vera van Randwijk, Annelies Rietdijk, Hinke Stellingwerf, Cora Tabak, Rix ten Veen, Regina in't Veld, Cisca Versluys, Mireille Westbroek, and Jantine van Woerden for general cooperation and their assistance in data collection; Jan Burema for statistical advice; and analysts Leslie Boogerd, Joke Barendse, Ronald Sperber, Truus Kosmeyer and Peter van de Bovenkamp for analyses of test meals and urine samples. 


\section{REFERENCES}

Acheson, K. J., Schutz, Y., Bessard, T., Ravussin, E., Jéquier, E. \& Flatt, J. P. (1984). Nutritional influences on lipogenesis and thermogenesis after a carbohydrate meal. American Journal of Physiology 246, E62-E70.

Bogardus, C., Lillioja, S., Ravussin, E., Abbott, W., Zawadzki, J. K., Young, A., Knowler, W. C., Jacobowitz, R. \& Moll, P. (1986). Familial dependence of the resting metabolic rate. New England Journal of Medicine 315, 96-100.

Bonsnes, R. W. (1978). Nitrogenous indices. In Laboratory Indices of Nutritional Status in Pregnancy, pp. 89-108 [Committee on Nutrition of the Mother and Preschool Child, editors]. Washington, DC: National Academy of Sciences.

Contaldo, F., Scalfi, L., Coltorti, A., Di Palo, M. R., Martinelli, P. \& Guerritore, T. (1987). Reduced regulatory thermogenesis in pregnant and ovariectomized women. International Journal for Vitamin and Nutrition Research 57, 299-304.

D'Alessio, D. A., Kavle, E., Mozzoli, M. A., Smalley, K. J., Polansky, M., Kendrick, Z. V., Owen, L. R., Bushman, M. C., Boden, G. \& Owen, O. E. (1988). Thermic effect of food in lean and obese men. Journal of Clinical Investigation 81, 1781-1789.

de Benoist B., Jackson A. A., Hall J. St. E. \& Persaud C. (1985). Whole body protein turnover in Jamaican women during normal pregnancy. Human Nutrition: Clinical Nutrition 39C, 167-179.

Durnin, J. V. G. A., McKillop, F. M., Grant, S. \& Fitzgerald, G. (1987). Energy requirements of pregnancy in Scotland. Lancet ii, 897-900.

Fitch, W. L. \& King, J. C. (1987). Protein turnover and 3-methylhistidine excretion in non-pregnant, pregnant and gestational diabetic women. Human Nutrition: Clinical Nutrition 41C, 327-339.

Flatt, J. P. (1985). Energetics of intermediary metabolism. In Substrate and Energy Metabolism, pp. 58-69 [J. S. Garrow and D. Halliday, editors]. London: John Libbey.

Forsum, E., Sadurskis, A. \& Wager, J. (1988). Resting metabolic rate and body composition of healthy Swedish women during pregnancy. American Journal of Clinical Nutrition 47, 942-947.

Grande, F. (1968). Energy balance and body composition changes. A critical study of three recent publications. Annals of Internal Medicine 68, 467-480.

Gutman, I. \& Bergmeyer, H. U. (1974). Urea. In Methods of Enzymatic Analysis, pp. 1791-1798 [H. U. Bergmeyer, editor]. New York: Verlag Chemie Weinheim and Academic Press.

Hytten, F. E. (1980a). The alimentary system. In Clinical Physiology in Obstetrics. Part 2. Nutrition and Metabolism, pp. 147-162 [F. E. Hytten and G. Chamberlain, editors]. Oxford: Blackwell Scientific Publications.

Hytten, F. E. $(1980 \mathrm{~b}$ ). Weight gain in pregnancy. In Clinical Physiology in Obstetrics. Part 2. Nutrition and Metabolism, pp. 193-233 [F. E. Hytten and G. Chamberlain, editors]. Oxford: Blackwell Scientific Publications.

Illingworth, P. J., Jung, R. T., Howie, P. W. \& Isles, T. E. (1987). Reduction in postprandial energy expenditure during pregnancy. British Medical Journal 294, 1573-1576.

Jéquier, E. (1981). Long-term measurement of energy expenditure in man: direct or indirect calorimetry. In Recent Advances in Obesity Research, vol 3, pp. 130-135 [P. Björntorp, M. Cairella and A. N. Howard, editors]. London: John Libbey.

Murgatroyd, P. R., Davies, H. L. \& Prentice, A. M. (1987). Intra-individual variability and measurement noise in estimates of energy expenditure by whole body indirect calorimetry. British Journal of Nutrition 58, 347-356.

Nagy, L. E. \& King, J. C. (1984). Postprandial energy expenditure and respiratory quotient during early and late pregnancy. American Journal of Clinical Nutrition 40, 1258-1263.

Piers, L. S., Soares, M. J., Makan, T. \& Shetty, P. S. (1992). Thermic effect of a meal. I. Methodology and variation in normal young adults. British Journal of Nutrition 62, 165-175.

Prentice, A. M., Goldberg, G. R., Davies, H. L., Murgatroyd, P. R. \& Scott, W. (1989). Energy-sparing adaptations in human pregnancy assessed by whole-body calorimetry. British Journal of Nutrition 62, 5-22.

Snedecor, G. W. \& Cochran, W. G. (1979). Statistical Methods, p. 113. Ames, Iowa: The Iowa State University Press

Thongprasert, K., Tanphaichitre, V., Valyasevi, A., Kittigool, J. \& Durnin, J. V. G. A. (1987). Energy requirements of pregnancy in rural Thailand. Lancet ii, 1010-1012.

Tuazon, M. A. G., van Raaij, J. M. A., Hautvast, J. G. A. J. \& Barba, C. V. C. (1987). Energy requirements of pregnancy in the Philippines. Lancet ii, 1129-1130.

van Raaij, J. M. A., Schonk, C. M., Vermaat-Miedema, S. H., Peek, M. E. M. \& Hautvast, J. G. A. J. (1987). Energy requirements of pregnancy in the Netherlands. Lancet ii, 953.955.

van Raaij, J. M. A., Schonk, C. M., Vermaat-Miedema, S. H., Peek, M. E. M. \& Hautvast, J. G. A. J. (1989). Body fat mass and basal metabolic rate in Dutch women before, during, and after pregnancy: a reappraisal of energy cost of pregnancy. American Journal of Clinical Nutrition 49, 765-772.

Weststrate, J. A. \& Hautvast, J. G. A. J. (1990). The effects of short-term carbohydrate overfeeding and prior exercise on resting metabolic rate and diet-induced thermogenesis. Metabolism 12, 1232-1239.

Williams, C. M., Pipe, N. G. \& Coltart, T. M. (1986). A longitudinal study of adipose tissue glucose utilization during pregnancy and the puerperium in normal subjects. Human Nutrition: Clinical Nutrition 40C, 15-23. 